\title{
'Between life and death': On land, silence and liberation in the capital city
}

\begin{tabular}{|c|c|}
\hline \multicolumn{2}{|c|}{$\begin{array}{l}\text { Author: } \\
\text { Stephan F. de Beer }{ }^{1}\end{array}$} \\
\hline \multicolumn{2}{|c|}{$\begin{array}{l}\text { Affiliation: } \\
{ }^{1} \text { Centre for Contextual } \\
\text { Ministry, University of } \\
\text { Pretoria, South Africa }\end{array}$} \\
\hline \multicolumn{2}{|c|}{$\begin{array}{l}\text { Note: } \\
\text { This article was initially } \\
\text { a presentation to the } \\
\text { Symposium Social Cohesion } \\
\text { 2013, directed by Prof. Dr } \\
\text { Johann-Albrecht Meylahn, } \\
\text { Department of Practical } \\
\text { Theology, Faculty of } \\
\text { Theology, University of } \\
\text { Pretoria, Pretoria, } \\
\text { South Africa. }\end{array}$} \\
\hline \multicolumn{2}{|c|}{$\begin{array}{l}\text { Correspondence to: } \\
\text { Stephan de Beer }\end{array}$} \\
\hline \multicolumn{2}{|c|}{$\begin{array}{l}\text { Email: } \\
\text { stephan.debeer@up.ac.za }\end{array}$} \\
\hline \multicolumn{2}{|c|}{$\begin{array}{l}\text { Postal address: } \\
\text { PO Box 11047, Tram Shed } \\
\text { 0126, South Africa }\end{array}$} \\
\hline \multicolumn{2}{|c|}{$\begin{array}{l}\text { Dates: } \\
\text { Received: } 28 \text { Sept. } 2013 \\
\text { Accepted: } 07 \text { Apr. } 2014 \\
\text { Published: } 01 \text { Aug. } 2014\end{array}$} \\
\hline \multicolumn{2}{|c|}{$\begin{array}{l}\text { How to cite this article: } \\
\text { De Beer, S.F., 2014, } \\
\text { "“Between life and death": } \\
\text { On land, silence and } \\
\text { liberation in the capital city', } \\
\text { HTS Teologiese Studies/ } \\
\text { Theological Studies 70(1), } \\
\text { Art. \#2075, } 7 \text { pages. http:// } \\
\text { dx.doi.org/10.4102/hts. } \\
\text { v70i1.2075 }\end{array}$} \\
\hline \multicolumn{2}{|c|}{$\begin{array}{l}\text { Copyright: } \\
\text { (C) 2014. The Authors. } \\
\text { Licensee: AOSIS } \\
\text { OpenJournals. This work } \\
\text { is licensed under the } \\
\text { Creative Commons } \\
\text { Attribution License. }\end{array}$} \\
\hline \multicolumn{2}{|l|}{ Read online: } \\
\hline 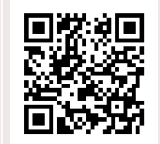 & $\begin{array}{l}\text { Scan this QR } \\
\text { code with your } \\
\text { smart phone or } \\
\text { mobile device } \\
\text { to read online. }\end{array}$ \\
\hline
\end{tabular}

This article reflects on the unfinished task of liberation - as expressed in issues of land - and drawing from the work of Franz Fanon and the Durban-based social movement Abahlali baseMjondolo. It locates its reflections in four specific sites of struggle in the City of Tshwane, and against the backdrop of the mission statement of the Faculty of Theology at the University of Pretoria, as well as the Capital Cities Research Project based in the same university. Reflecting on the 'living death' of millions of landless people on the one hand, and the privatisation of liberation on the other, it argues that a liberating praxis of engagement remains a necessity in order to break the violent silences that perpetuate exclusion.

\section{Introduction}

Many urban spaces in the City of Tshwane have become sites of struggle between life and death. In the year of remembering the Native Land Act of 1913, we also have to consider the contemporary and ongoing struggles for land, for the right to the city, and - more essentially - for being human.

In the city the struggle for being human is often connected to struggles for land. Struggling in urban spaces, forever being under threat of eviction or removal, or criminalised for being poor, mediate the reality of what Franz Fanon (1967:12) called 'the living death'.

This article reflects on the unfinished task of liberation, as expressed in issues of land, and drawing from the work of Fanon and the Durban-based social movement Abahlali baseMjondolo. It would locate its reflections in four specific sites of struggle in the City of Tshwane, envisioning engaged scholarship and shifting geographies of reason.

This article would like to offer its reflections against two institutional backdrops:

- The mission statement of the Faculty of Theology at the University of Pretoria is committed to 'life-giving theology' that, amongst other things, seeks to 'promote justice' and engages 'people on the margins of society'.

- The most recently launched Institutional Research Theme (IRT) of the University of Pretoria, entitled 'Capital Cities: Space, Justice and Belonging' ${ }^{2}$, explores how space, justice and belonging are expressed in the City of Tshwane, in conversation with other capital cities in the global south.

I would like to argue that a liberating praxis of engagement is (still) a necessity in conjunction with and initiated by concrete sites of struggle in order for violent silences to be broken, for the disruptions of the poor to penetrate our numbness, and for the mutual liberation of the poor and of theology to continue.

\section{Life-giving theology, promoting justice and engaging people on the margins ...}

In a context of the 'living death', of struggles for land and the right to the city, of just being human, what would life-giving theology look like? In a postcolonial city, or some would argue a neocolonial city, where the balance of power still lies with white capital determining future cityscapes, where would such theology locate itself? Who will be its interlocutors? Which and whose knowledge will it engage, value or retrieve?

If life-giving theology includes the promotion of justice, peace and the integrity of creation, what does it mean in concrete terms in a city where the basic dignity of humans are violated on city streets and in informal settlements on a daily basis? Can we even speak of justice without those 1.Strategic Plan: Faculty of Theology, approved by the University Executive in August 2013.

2.Approved by the University Executive in April 2013, University of Pretoria. 
experiencing injustices existentially informing our discourse on justice? What does it mean to promote justice as theological educators, and how concrete do we become? Does it require of us to be engaged as activists or scholars, or can we afford to speak of justice philosophically without the death-dealing realities of urban slums and informal settlements affecting us personally? Can we do theology with integrity in ways which are detached?

If we speak of life-giving theology there is for me at least the assumption of a desire to respond to the realities of death-dealing locations and situations in our midst. We are all confronted with the struggle between life and death, but in a particular sense, the margins of our cities are sites of struggle where life and death are in a constant dance to outwit each other.

I understand life-giving theology as theology that is able to name death - the robber of John 10 that steals, kills and destroys; to name discourses about power and poverty that perpetuate oppression; whilst at the same time creating spaces, tables and conversations that could mediate life in abundance, and the possibility of human and communal flourishing.

It is most often on the margins where justice does not trickle down. It is often the systemic and spatial injustices and the ways in which capital and resources are organised that create marginal communities.

Perhaps we need to consider the more fundamental question of whether we simply want to engage the margins, occasionally, and on our terms, or whether it is necessary to actually move the margins to the centre - for the margins to become the localities, the geographies of our theological reflection and action.

\section{Capital cities: Space, justice and belonging}

The University of Pretoria has recently launched a new IRT entitled 'Capital Cities: Space, Justice and Belonging'. Its mandate is to conduct research related to the City of Tshwane in how it deals with issues related to space, justice and belonging, in comparison to other capital cities in the global south.

And yet, there is almost a sense in which the theme of this IRT is itself contradictory, because capital cities by definition are not necessarily placing as highest priority the mediation of space that evokes a sense of justice or belonging:

To mask the fact that the city is, in fact, not really open to all, and that the idea of the liberated nation is stagnating, the nationalist bourgeoisie assures itself by erecting 'grandiose buildings in the capital'; instead of encouraging the building of sustainable communities, it lays out 'money on what are called prestige expenses. (Fanon 1968:165; cf. Gibson 2011:25)
World Cup soccer stadiums, struggle monuments and new headquarters for various government departments all represent monumentality instead of reality, imagery creating the illusion of a prosperous and free state whilst marginal populations are often displaced to make way for the very same monuments.

Huchzermeyer (2008:53) reflects on the City of Tshwane's 'slum eradication' programme hailed as best practice by the provincial department of housing. In terms of informal settlements, the 'key to successfully managing "mass invasions" was the shifting of resources away from basic needs such as water supply and into the employment of private security companies' (Gibson 2011:152). The city invests not in supporting social and physical infrastructure to accommodate the poor but invest in keeping the poor out.

So how do we engage our city as a university? Which city do we engage? Do we engage the political powers that be, or the sites of struggle, or both? Do we practise a certain bias? Do we allow for a multiplicity of engagements of different kinds and textures?

Is the university free enough to practice rigorous engagement and honest research that might even be at odds with the powers that be of the city? Or does the university have vested interests that would guard against the kinds of critical engagement that might be required to build a good and just city?

\section{Between life and death: Sites of struggle across the city}

Space, in the words of Elden (2007:822), has become 'the ultimate locus and medium of struggle' in post-apartheid cities (cf. Gibson 2011:27). For the annual city festival, Feast of the Clowns ${ }^{3}$, students of information design at the university worked with inner city residents to design, amongst other things, a protest map, delineating sites of struggle across the city. Almost every second inner city property represents a struggle for life and death, for the soul of the building, and the dignity of its residents.

In this article I briefly map four specific sites of struggles. All four sites are owned by government, three by local government (i.e. the City of Tshwane), and one by national government.

\section{Site 1: Schubart Park}

Schubart Park is a complex of four high-rise buildings of 20 stories each, built in the 1970s with Dutch investment for low-income white families. Since the 1990s, the properties changed completely in terms of its racial composition, and provincial government devolved ownership and management of the property to local government. The city never had the capacity to take on this management challenge to start with, and management collapsed during this period.

3.http://www.feastoftheclowns.org.za 
Over more than 10 years the situation deteriorated resulting in massive overcrowding; by the end of occupation in September 2011, no elevators were working although people still lived on the 20th floor of the building, water was leaking from the top floor through to the basement, fires broke out occasionally in individual apartment units in the complex, illegal electricity connections became wide-spread, and nonpayment of rentals became the norm.

Finally, in September 2011, more than 847 families or 3000 people were evacuated from the building. On the day when the so-called evacuation took place, the city had no alternative accommodation prepared for the 847 families. Streets around Schubart Park were cordoned off for more than a week and people who could not be assisted in churches or faith-based organisations, were camping on the streets until the city found temporary alternatives.

The city government used the term 'evacuate' instead of 'evict', suggesting that the property was uninhabitable, but this was never proven. More than a year later, in October of 2012, the Constitutional Court ordered in favour of the tenants citing the fact that the eviction from Schubart Park was in fact illegal; no proper eviction order was obtained, no alternatives were prepared in advance, and the buildings were not beyond repair. The Constitutional Court ruled that the city had to either allow the tenants to move back to Schubart Park or that the tenants had to be given viable, alternative and long-term options with immediate effect (Berkowitz 2012; Mbanjwa 2012).

By September of 2013, almost one year since the ruling of the Constitutional Court, the city for the first time secured long-term alternatives for these families. Two years of people's lives had been destabilised - people with babies, preschool children, primary school children, high school children and single mother families; apart from the physical displacement, they were traumatised and kept from consolidating their lives.

In the aftermath of the 'evacuation', the media were fed with distorted facts about the number of illegal citizens in the buildings, the crime elements, and so forth. The presence of ordinary families, school-going children and some elderly people were not accentuated. The fact that it was the city's own property all along, and had been mismanaged for years, was seldom mentioned in court or in the media. One perspective was that the buildings were hijacked and made unmanageable. Another perspective is that the city deliberately allowed the buildings to deteriorate to a point of no return to enable them to displace the tenants and to create an environment that would attract people of greater means to the same location.

\section{Site 2: Woodlane Village}

Woodlane Village is not a quaint English country village, but one of the only informal settlements that is also a gated community, if not the only one, situated in the east of Pretoria, opposite the upmarket shopping mall, the Woodlands Boulevard, the award-winning Woodhill Golf Estate, a number of upmarket security villages, and adjacent to the biggest church in Pretoria, the Moreletapark Dutch Reformed Church.

Also known by some as Plastic City, although not nearly communicating the same as Woodlane Village, the informal settlement is located on a 70 hectare portion of land owned by the city, and now occupied by almost 3000 people living in informal dwellings on this land.

Surrounded by gated communities, five resident associations at some point took the city to court for allowing the informal settlement, citing crime and the fact that the settlement was affecting their property values as main reasons for taking legal action.

In 2006, a series of demolitions of people's shacks took place; this action was executed by the police and municipal authorities. On every occasion the actions of the police and municipality were reversed by court orders that instructed the authorities to rebuild the shacks. Finally, the Constitutional Court ruled in 2011 that the city had to come up with an integrated development plan for the land, which had to include the residents of this informal settlement. This plan was due to be executed during September 2012, but by September 2013 the city had not yet indicated its plans for the land (cf. Du Preez 2012; Tswelopele 2009).

The irony of it all is that many of the residents of Woodlane Village work as domestic workers, gardeners or labourers for residents or businesses in the area, or on building sites where construction takes place; others are unemployed. Another irony is that the Woodhill Golf Estate in 2012 won an award as the golf estate in the country with the greatest increase in property prices. The argument that the presence of the informal settlement affected property prices in the area was ironically contradictory.

\section{Site 3: Salvokop}

Salvokop is an old railway community behind the Pretoria Central Station. The land is owned by the Department of Public Works. It has 174 houses and residents of diverse racial and ethnic backgrounds, including both South African and African residents (cf. Tshwane Leadership Foundation n.d.).

Most of the houses are occupied by tenants with legal rental contracts. Many more tenants live in backyard shacks allowed by the formal tenants who sublet their properties. In addition, there is now also Bagdad, a growing informal settlement against the western hill of Salvokop. An estimated population of 3000 people live in Salvokop.

Ironically, on the southern hill of Salvokop sits the latest pride of Tshwane, the Freedom Park monument, a struggle monument juxtapositioned with the old 
Afrikaner Voortrekker Monument, and linked by the new Reconciliation Road.

As early as 1998, the then landlord (at that stage it was owned by Propnet, a government-owned entity looking after government-owned, transport-related properties) called for development proposals for this area. The faithbased organisation I was part of at that stage, together with other local non-profit agencies, the local residents and the local primary school, created a consortium and engaged a professional team to envision and draft an integrated development proposal that would facilitate the growth and development of the area, but also to ensure the inclusion of the tenants of the area. In 1998 there were no shacks in the area and there was an opportunity to develop a model inner city neighbourhood demonstrating high levels of diversity and social inclusion. None of the development proposals were considered, and 15 years later the situation has grown almost out of control.

This land offers an ideal site for gentrification, being close to major transport nodes, a range of government headquarters, and the capital city's Central Business District. It could very well be redeveloped at the expense of the people who lived there for the past 20 years or more in some cases. Salvokop will probably be one of the next highly contested sites in the City of Tshwane (cf. Mbanjwa 2012).

\section{Site 4: Westfort Village}

Westfort Village is a historic site that housed a leprosy hospital and accommodated patients from Robben Island once Robben Island was converted from a leprosy hospital to a prison. Westfort Hospital also served the overflow from the psychiatric hospital and was the only hospital in South Africa that also had a prison inside of it so that lepers could not escape. Four churches had buildings and worshipping communities in this village. Also of significance is the cemetery that not only reminds one of patients and staff of the hospital that were buried here, but this site also hosted a cemetery dating back to the Anglo-Boer War.

In the early 1980s, the hospital closed down, the churches were abandoned by their denominations, and over time this site of national heritage importance became occupied by people moving into the houses, rooms, churches and other properties on the site. Today a community of more than 2000 people live on this land. The city apparently has plans, together with provincial government, to redevelop this and adjacent portions of land for residential use. Neither the South African Heritage Resource Association (SAHRA), nor the residents and different researchers from the University of Pretoria all seeking access to relevant information from the city or province as to the nature of the future development plans, were successful in their attempts. The people living on this land have not been consulted by politicians in terms of their aspirations for inclusion or exclusion from future land development plans - this is another contested terrain (cf. Fraser 2007; South African Broadcasting Corporation 2012; SAHRA n.d.).

\section{On land, silence and liberation Urban land and the unfinished business of liberation}

Gibson (2011:xii) writes that the struggle for the right to the city in South Africa can also be understood as part of the continuing struggle for liberation'. It is 'synonymous with the struggle against a living death' (Gibson 2011:xvi).

This struggle is often a struggle or politics of space. It is in urban spatial patterns that we witness the fractures in society with gated communities on the one hand, and informal settlements or so-called illegal occupations on the other, often coexisting in close proximity to each other (cf. Gibson 2011:xvi). In response to these global and urban fragmentations, we now see on the one hand, an increasing mobilisation of grass-roots movements around the 'right to the city', insisting on finding a foothold in the city, but on the other hand, where the market fails to exclude the poor, government intervenes through militarising city spaces, illegal evictions and the criminilisation of the poor, ensuring the existence of neocolonial enclaves that keep the disruptions of the poor outside the walls (cf. Gibson 2011:xvi;72;188).

Abahlali baseMjondolo is a 'shack dweller movement' originating in Durban representing such a new social movement. When the police wanted to evict these shack dwellers from where they lived in Kennedy Road, they barricaded the road, prevented displacement and insisted that there were no alternatives for people like them.

Lefebvre, Abahlali and others articulate the actions of the poor claiming their right to the city, as more than a demand for rights, but as a fundamental affirmation of life (Gibson 2011:xvi; Lefebvre 1992:201, 1996:158), a cry for a new way of being human in the city, promoting the democratisation of the city from below.

Those who are evicted from city land or property because they are supposedly illegal have the right to ask what 'illegal' means. As Abahlali stated in a press release issued directly after the xenophobic attacks in May of 2008:

Our struggle and every real struggle is to put the human being at the centre of society, starting with the worst off. An action can be illegal. A person cannot be illegal, a person is a person wherever they may find themselves. (Gibson 2011:21)

The press speaks of humanity in relation to land and of land in relation to humanity. The people living in Salvokop or Westfort, those evicted from Schubart Park, or those homeless individuals living on pavements, are part of this continuing struggle for liberation.

The visions of post-apartheid city managers are often in direct opposition to the visions of radically inclusive cities, seen from below. The one vision excludes the poor (consider Braamfontein, the new Cape Town City Centre or the new Point Road in Durban); the other vision includes the poor fundamentally (cf. Gibson 2011:19). For Fanon (1967:45), such 
a radically inclusive city is an expectation and an outcome of a more 'total liberation'.

The one is a vision displacing the poor in the name of slum clearance and development, but it is development equated with exclusivist economic growth and privatised liberation at the expense of the masses at the bottom. The other is a vision of a city with human beings at the core, and then in particular the most vulnerable amongst us.

In theological discourse we often, and perhaps too fast, wanted to move beyond liberation to reconstruction, but, says Fanon (1968:127), the poor 'had never ceased to think of liberation'. Unlike the privatised beneficiaries of liberation, or those vested in the academy who simply sighed in relief when the revolution came to an end, or the private sector that is better off than preliberation as their own interests have just been strengthened, the poor had not ceased to think of liberation, because they are still facing the 'living death'.

The challenge of the post-apartheid city and society is that there was in many ways simply a handover of the torch, but the radical reorganisation of the city that was required after the spatial engineering of apartheid that so segregated functions and people has not occurred (cf. Gibson 2011:25).

\section{Silence, privatised liberation and a 'living politics'}

S'bu Zikode of Abahlali says, 'one of the deep problems of our society is that liberation has been privatized' (Gibson 2011:vii). Those benefiting from liberation, privatised it at the expense of the collective, and according to Gibson (2011:25), this would constitute for Fanon 'the reality of the neo-colonial city' where those formerly colonised now adopt the ways of the coloniser. The prophets Isaiah and Micah give clear accounts of just how such handovers of power from oppressor to oppressed can turn out at the expense of the poor (cf. Is 5:8; Mi 2:2; 6:1-8).

Zikode speaks of it in reference to gated walls, ethnic and party politics, asserting that:

These walls do not only divide us physically, they are also there to teach us that liberation has been privatized and that success is getting yourself and your family on the right side of the walls. (Gibson 2011:xiii)

Or, as Gibson (2011:vii) says, 'people are scared to accept the reality of equality because it is incompatible with the privatization of liberation'.

Neoliberal or neocolonial dependency on capital investment has co-opted and silenced the small elite groups of beneficiaries of black economic empowerment, who, privatising liberation for themselves and their children, also become the agents of domestication of the rowdy crowds who are on the outside looking in, not sharing in the benefits of socalled liberation (cf. Gibson 2011:xiv;121). The 67 minutes of charity on Mandela's birthday is a mirror image of the escape of the elite from urban townships, informal settlements and inner cities, numbing our consciousness at the expense of imagining and mediating more radical alternatives to what are in existence.

Attempts to silence grass-roots movements that resist their own death and exclusion, or putting them back 'to the caves' (Fanon 1968:183) is often the work of postcolonial powers. Trade unions and community leaders were often co-opted into political power, post-apartheid, which means they were silenced into compliance (cf. Gibson 2011:13).

Our schools of theology are often co-opted into being schools of domestication instead of liberation. We tame people for the church. And, says Gibson (2011:33), non-governmental organisations (NGOs) often create new dependencies of victimhood continuing the work of mental colonisation at the expense of nurturing consciousness and agency.

In response to the silencing of neocolonialism and in contrast to a kind of humanitarianism practised by NGOs, churches and others of good will that merely replace the coloniser in taking away people's agency, Fanon, Gibson and others propose a 'living politics'; that is, a politics in response to the daily 'living death' (Fanon 1967:12) located in the daily struggles of life and death, a politics of new humanism, as Fanon would call it, that arises from a new affirmation of own worth, a new consciousness to use the words of Biko, subverting the worthlessness put upon the poor (Fanon 1968:67).

In Abahlali this is expressed in their insistence not to be spoken about, but to be spoken with (Gibson 2011:xv). They insist that their protests are not about service delivery, which would just keep them dependent on the good will and handouts of government officials and politicians; their protests are about a new way of doing politics, a democratisation from below, an assertion of their participation in determining their own futures, a cry for a new way of being human together. However, it goes much deeper as it is essentially a moral struggle to redefine our common humanity in the city. It is a disruption of an elitist concept of the city and its socio-spatial-political order; it seeks the completion of liberation for all.

The new social and land movements mediate what Biko and Fanon argued for, namely the 'death of the slave' (Gibson 2011:17) which starts not with external change but with internal or mental change of both slave as well as internalised master. The sudden articulation of the poor, often disruptive and loud, presents a challenge to the 'civilized' postcolonial regime presenting a facade of freedom for all. As local communities on the margins develop a sense of consciousness about their own worth, coupled with newfound agency, they discover that they are on their own and that long-term liberation will depend on their own actions and assertions (cf. Gibson 2011:40). 
Movements such as Abahlali represent a clear break with a post-apartheid and elitist concept of the city, disrupting the socio-political-spatial order of the city, in order to work towards the completion of liberation for all (cf. Gibson 2011:23).

\section{Shifting the geography of reason: On engaged scholarship and liberation}

In this context, Abahlali refuses to be the objects of research and rather suggests as the vocation of engaged scholars 'to find new ways of listening to those who continue to be silenced and dehumanised' (Gibson 2011:40) and to help break the silence and articulate in fresh ways what they hear.

Is it possible to foster theologies with an intentionality to listen to 'the voices and thinking that come from unexpected spaces, namely, the new movements from below' (Gibson 2011:6)? Fanon (1968:146) speaks of it as 'shifting the geography of reason'; a new locatedness on the margins, or as Zikode (Gibson 2011:vi) suggests, borrowing from Fanon, to be 'inside the struggles of the people and ... inside the discussions inside the struggles of the people'.

In shifting the geography of reason, Fanon suggests 'finding new sources or truth and reality' (Gibson 2011:8) that will help us see the city from vastly new and different angles, to read the city 'from below', and there to struggle with questions of what life and justice could mean in the midst of 'living death'. Instead of bringing intelligence to the people like the missionary, the site of struggle itself becomes the source of a new way of knowing' (Gibson 2011:8).

According to Zikode, the shack dwellers movement is a university where they 'think their own struggles' and 'are not poor in mind' (Gibson 2011:179). The challenge of Zikode is 'to bring "our university" [Abahlali] to "your university"' opening up reciprocal possibilities for new and mutually liberating knowledge to unfold (Gibson 2011:179).

However, Fanon (1968:48) warned that this should not be uncritical, or as Gibson (2011:177) says, 'the point is not to praise the masses but to engage with them'. Part of the function of the engaged scholar is to accompany people on the margins as they discover 'that they cannot rely on imaginary or iconic leaders' (Gibson 2011:177), as they discover their own agency, and as they start to articulate the new city of their imagination. Another function of the engaged scholar could be 'not only to battle the privatization of space, but to open new spaces in which a humanism can be voiced and discussed' (Gibson 2011:143).

An example could be to broker spaces for policy conversations that include the poor at the table. As Zikode (2006:185) says:

we believe that the housing policy does not only require housing specialists, rich consultants, and government. We believe that housing policy requires most importantly, the people who need the houses. (p. 185)
Such spaces could affirm the agency of people who, from within their own lived experiences, participate in carving out desirable and mutually inclusive and interconnected futures, with those who have the technical expertise.

When I studied theology at the University of Pretoria it was between 1986 and 1991 through two States of Emergency, the operations of death squads, people dying in townships and on the country's borders, conscription and anticonscription. And yet, through all of those death-dealing years and amidst a crisis of utmost proportions, we were trained to become theologians with almost no connectedness whatsoever to any of those realities doing theology mostly in a vacuum. Could it be possible that even today, amidst the new crises staring us in the face, we simply do not see, as theologians and schools of theology, because we are too far removed from such realities?

As someone wrote from prison during that time (South African History Archive 1990):
In this land of civil war
And walls set out between our
Hearts
No one is free
But some dream of freedom
While others build fortresses

It seems as if little has changed since then - some dream of freedom whilst others build fortresses.

Should not that be the soil for discovering life-giving theology and visions of justice - to connect with, as Gibson (2011:143) says, those 'who are living their lives in a daily state of emergency', in sites of struggle around our city, 20 years after 'freedom has come'; to make those the central spaces of our theological engagement, for the mutual liberation of both theology and the poor?

\section{Acknowledgements Competing interests}

The author declares that he has no financial or personal relationship(s) that may have inappropriately influenced him in writing this article.

\section{References}

Berkowitz, P., 2012, 'On the street where you lived: What next for Schubart Park?', The Daily Maverick, viewed 12 October 2012, from http://www.dailymaverick.co.za/ article/2012-10-12-on-the-street-where-you-lived-what-next-for-schubart-park/

Du Preez, Y., 2012, 'Woodlane villagers dream of real home at last', Pretoria News, viewed 15 January 2014, from http://www.iol.co.za/pretoria-news/woodlanevillagers-dream-of-real-homes-at-last-1.1315003\#.U4YiwrcaLIU

Elden, S., 2007, 'Terror and territory', Antipode 39, 821-845. http://dx.doi. org/10.1111/j.1467-8330.2007.00554.x

Fanon, F., 1967, Black skin, white masks: The experiences of a black man in a white world, transl. C.L. Markmann, Grove Press, New York.

Fanon, F., 1968, The wretched of the earth, transl. C. Farrington, Grove Press, New York.

Fraser, B., 2007, 'Hard lives in old leper hospital', Sowetan, viewed 15 January 2014 from http://www.sowetanlive.co.za/sowetan/archive/2007/04/13/hard-lives-inold-leper-hospital

Gibson, N.C., 2011, Fanonian practices in South Africa, Palgrave Macmillan, London. 
Huchzermeyer, M., 2008, 'South Africa's approach to eradicating informal settlements: An urgent call for change, Trialog 98(March), 48-53.

Lefebvre, H., 1992, The production of space, Blackwell, Oxford.

Lefebvre, H., 1996, Writings on cities, Blackwell, Oxford.

Mbanjwa, X., 2012, 'Schubart Park eviction unlawful - ConCourt', City Press, viewed 09 October 2012, from http://www.news24.com/SouthAfrica/News/ConCourtSchubart-Park-eviction-unlawful-20121009

'No freedom for the poor on this park', City Press n.d., viewed 04 August 2013, from http://152.111.1.87/argief/berigte/citypress/2009/07/27/CP/12/mwkop.html

South African Broadcasting Commission, 2012, 'Episode of 15 July 2012', in ddbe53004bf671e7a389af8b30ab6902/Fokus,-15-July-2012-20120713
South African History Archive, 1990, Long live flat feet: Long leave, objector, AprilMay 1990, AL2457, the Original SAHA Collection, E6.4.5

South African Heritage Resources Agency n.d., Westfort Leper Hospital and Fort Daspoortrand, viewed 04 August 2013, from http://www.sahra.org.za/cases/ west-fort-leper-hospital-fort-daspoortrand

Tshwane Leadership Foundation n.d., Inkululeko Community Centre, viewed 04 August 2013, from http://www.tlf.org.za/icc.htm

Tswelopele, 2009, 'Step by Step', in Woodlane Village, viewed 04 August 2013, from http://www.tswelopele-sa.org.za/index.php?page=woodlanevillageprojects

Zikode, S'bu, 2006, 'We are the third force', Journal of Asian and African Studies 41(1/2), 185-189. 